\title{
PERFORMA PRODUKSI DAN POTENSI PENDAPATAN USAHA TERNAK KAMBING PERAH DI KABUPATEN LUMAJANG
}

\author{
A.F. Prasetyo ${ }^{1}$, Nurkholis ${ }^{2}$ \\ ${ }^{1,2}$ Staf Pengajar Jurusan Peternakan Politeknik Negeri Jember \\ Jalan Mastrip PO BOX 164 Jember \\ ${ }^{1)}$ email : anangfebri@polije.ac.id
}

\begin{abstract}
ABSTRAK
Penelitian ini bertujuan untuk mengetahui produktivitas ternak kambing dan potensi ekonomi peternak kambing etawa senduro di daerah sumber bibit Kambing etawa senduro. Penelitian ini telah dilaksanakan pada Juli - Agustus 2018 di Kabupaten Lumajang, Jawa Timur. Responden dalam penelitian ini di pilih dengan metode purposive, yaitu responden yang hanya memelihara atau mengembangkan ternak kambing etawa senduro. Sejumlah 76 responden telah di wawancara menggunakan kuesionare untuk mendapatkan data sosial ekonomi dan potensi ternak kambing etawa senduro. Data yang diperoleh dianalsis secara diskriptif untuk menggambarkan profile peternak, kepemilikan ternak, dan potensi ekonomi ternak. Hasil penelitian ini diperoleh bahwa Jumlah kambing yang dipelihara oleh peternak sebanyak 12.27 \pm 9.62 ekor, sudah menguntungkan secara ekonomi bagi peternak. Sistem perkawinana secara alami dapat meningkatkan performa ternak kambing etawa. Usaha ternak kambing etawa senduro di kabupaten lumajang memiliki potensi besar sebagai penghasilan peternak yaitu mencapai 9.660.000/tahun dari penjualan cempe dan pendapatan harian sebesar Rp. 50.496/hari dari penjualan susu.
\end{abstract}

\section{Kata Kunci : Produktivitas ternak, Potensi Ekonomi, Kambing Perah, Etawa Senduro}

\section{PENDAHULUAN}

Kambing peranakan etawah merupakan salah satu ras kambing Indonesia. Sudah banyak bibit kambing peranakan etawah disebarkan ke berbagai daerah di Indonesia untuk meningkatkan kinerja kambing lokal di daerah (Budiarsana et al., 2001). Salah satu ras kambing yang telah lama berkembang di daerah adalah kambing etawa senduro. Kambing ras senduro yang merupakan hasil persilangan Jamnapari ras Etawah dengan kambing lokal Lumajang (menggolo) (batubara, 2016).

Kambing peranakan etawah merupakan ternak dwi guna karena selain penghasil daging juga penghasil susu (Sarwono 1999). Kambing Peranakan Etawah memiliki ciri khusus, antara lain telinga yang panjang, menggantung dan terkulai, serta bulu rewos yang panjang pada ke dua kaki belakang dan memenuhi persyaratan mutu untuk pembiakan sebagai bibit, memiliki daya produksi dan reproduksi yang tinggi (BSN, 2008).

Keunggulan kambing peranakan etawah sudah banyak dilaporkan; diantaranya beradaptasi baik dengan lingkungan, termasuk kambing tipe dwi-guna dan memiliki 149 | Performa Produksi Dan Potensi Pendapatan Usaha Ternak Kambing Perah Di Kabupaten Lumajang 
indeks reproduksi yang cukup baik yaitu 1,65 anak/induk/tahun (Sodiq, 2001). Potensi produksi susu kambing pernah dilaporkan oleh Obst dan Napitupulu (1984) yaitu sebanyak. 0,45 - 2,1 1/hari/laktasi. Sementara itu produksi susu yang dilaporkan oleh Sutama et al. (2002) yaitu berkisar pada 510 - 1000g/ekor/hari.

Ternak kambing etawa sangat berpotensi untuk dikembangkan, karena termasuk ternak yang mempunyai adaptasi cukup tinggi dan cocok untuk meningkatkan perekonomian di pedesaan. Sekarang ini di daerah tropis produksi susu kambing mempunyai arti yang penting dan sedang digalakkan (Devendra \& Burns, 1994). Ternak kambing etawa bagi peternak merupakan salah satu aspek penting perekonomian keluarga. Bagi masyarakat pedesaan ternak kambing etawa telah menjadi budaya sebagai tabungan keluarga.

Dilapangan dapat dikatakan bahwa komersialisasi ternak kambing etawa belum banyak dilakukan, namun sudah ada tanda-tanda peningkatan skala kepemilikan. Hal ini dicirikan dengan semakin meningkatnya skala usaha. Dalam upaya mendapatkan informasi mengenai pentingya ternak kambing peranakan etawa bagi masyarakat pedesaan, maka penelitian ini bertujuan untuk menetahui produktivitas ternak kambing etawa dan pendapatan usaha ternak kambing peranakan etawa.

\section{MATERI DAN METODE}

\section{Waktu dan Tempat}

Penelitian akan telah dilaksanakan pada bulan Juli - Agustus 2018 di Kabupaten Lumajang, Jawa Timur. Lokasi peternak yang menjadi sampel dalam penelitian ini berada di dua Kecamatan yang sebagian besar peternak memelihara kambing peranakan etawa senduro yaitu di Kecamatan Pasrujambe dan Kecamatan Senduro.

\section{Materi}

Materi penelitian ini adalah 76 peternak yang mewakili di kedua kecamatan. Responden dipilih dengan metode purposive, yaitu peternak yang hanya mengembangkan ternak kambing etawa senduro.

\section{Metode}

Metode yang digunakan dalam penelitian ini adalah metode survey, data yang diambil berupa data primer dan data sekunder. Data primer di ambil dengan alat bantu kuesionare dengan cara mewawancarai responden, sedangkan data sekunder diambil dari instansi terkait. 


\section{Analisis data}

Data yang telah dikumpulkan ditabulasikan dalam Ms. Word excel dan dianalisis diskriptif menggunakan alat bantu software SPSS 17. for windows.

\section{Parameter penelitian}

Parameter penelitian yang diambil meliputi karakteristik peternak (Usia, tingkat pendidikan formal, informal, lama beternak, motivasi berternak). Kepemilikan ternak (tujuan pemeliharaan Jumlah kepemilikan ternak, jumlah Indukan, jumlah pejantan, jumlah anak). Potensi ekonomi ternak (rata rata produksi susu per hari, rata-rata kelahiran anak /tahun, rata-rata harga susu/liter, rata-rata harga cempe lepas sapih)

\section{HASIL DAN PEMBAHASAN}

\section{Gambaran Umum Lokasi Penelitian}

Kabupaten Lumajang merupakan salah satu daerah di Indonesia dengan sentra peternakan dan pertanian. Populasi ternak Kambing menururt kecamatan pada tahun 2018 sebagai berikut; Pronojiwo 6.496 ekor; Pasirian 8.551 ekor; Lumajang 438 ekor; Tekung 1.341 ekor; Yosowilangan 3.724 ekor; Rowokangkung 864 ekor; Sukodono 1.468 ekor; Senduro 23.335 ekor; Pasrujambe 16.401ekor; Gucialit 4.743 ekor; Kedungjajang 5.421 ekor, (Anonoim, 2018). Kecamatan Senduro dan Kecamatan pasrujambe memiliki populasi ternak kambing yang paling besar. Hal ini di dukung oleh potensi wilayahnya yang merupakan daerah pengunungan dengan ketinggian 500 - $700 \mathrm{~m}$ diatas permukaan air laut (dpl) dengan curah hujan $4.176 \mathrm{~mm}$ pertahun sehingga banyak hijauan yang tumbuh subur.

\section{Kepemilikan Ternak Kambing}

Tabel 1. Kepemilikan ternak

\begin{tabular}{lrc}
\hline Parameter & \multicolumn{1}{c}{ Nilai } & Persentase \\
\hline Tujuan pemeliharaan & & \\
Produksi susu & 31 Peternak & 40,78 \\
Penggemukan & 31 Peternak & 40,78 \\
Pembibitan & 14 Peternak & 18,44 \\
\hline Kepemilikan ternak & $12.27 \pm 9.62$ ekor & \\
Laktasi & $3.85 \pm 5.3$ ekor & \\
Kering & $2.77 \pm 2.82$ ekor & \\
Dara & $1.77 \pm 2.35$ ekor & \\
Pejantan & $1.80 \pm 3.33$ ekor & \\
Cempe & $2.93 \pm 4.67$ ekor & \\
\hline
\end{tabular}

Sumber : Data Terolah 2018

151 | Performa Produksi Dan Potensi Pendapatan Usaha Ternak Kambing Perah Di Kabupaten Lumajang 
Peternak kambing etawa senduro di daerah penelitian ini didapatkan tujuan pemeliharaan sebagai berikut; peternakan yang di tujukan sebagai penghasil susu sebanyak 40,78\%; usaha peternakan yang ditujukan untuk penggemukan sebesar $40,78 \%$; sedangkan sebagai pembibitan hanya $18,44 \%$. Hal ini menunjukkan bahwa tidak semua ternak peranakan etawa senduro diperah sebagai penghasil susu. Padahal kambing etawa senduro merupakan ternak kambing yang dersifat dwi guna, penghasil susu dan daging (Davendra dan Burn, 1994). Potensi produksi susu kambing pernah dilaporkan oleh Obst dan Napitupulu (1984) yaitu sebanyak. 0,45 - 2,1 1/hari/laktasi. Keunggulan kambing PE sudah banyak dilaporkan; diantaranya beradaptasi baik dengan lingkungan, termasuk kambing tipe dwi-guna dan memiliki indeks reproduksi yang cukup baik yaitu 1,65 anak/induk/tahun (Sodiq, 2001)

Jumlah kepemilikan kambing etawa senduro bervariasi, namun diketahui rata-rata kepemilikan kambing oleh peternak di daerah penelitian sebanyak $12.27 \pm 9.62$ ekor. Sesuai dengan hasil penelitian (Priyanto, at.al, 2014) skala kepemilikan ternak kambing etawa yang $>4,2$ ekor sudah menguntungkan. Hal ini menyatakan bahwa skala ekonomi usaha ternak kambing etawa di lokasi penelitian sudah tercapai, terlepas dari tujuan pemeliharaannya menunjukkan bahwa usaha peternakan kambing etawa yang di lakukan oleh masyarakat di lokasi penelitian sudah menguntungkan.

Proporsi populasi kepemilikan kambing etawa sendoro di masing-masing peternak, sesuai dengan Tabel 2, dapat di jelaskan sebagai berikut. Kepemilikan induk laktasi sebanyak 3.85 \pm 5.3 ekor; induk kering sebanyak $2.77 \pm 2.82$ ekor; kambing dara sebanyak $1.77 \pm 2.35$ ekor; kambing pejantan sebanyak $1.80 \pm 3.33$ ekor, dan cempe/anak kambing sebanyak $2.93 \pm 4.67$ ekor. Proporsi populasi kepemilikan kambing etawa senduro ini terlihat cukup bagus karena setiap peternak rata-rata memiliki pejantah, hal ini agar tidak terjadi inbreading yang dapat menurunkan produktivitas ternak kambing senduro.

\section{Performa Produktivitas Ternak}

Tabel 2. Parameter produktivitas ternak

\begin{tabular}{ll}
\hline Parameter & Nilai \\
\hline Sistem perkawinan & $100 \%$ Alami \\
Umur pertama birahi & $9.5 \pm 2.89$ bulan \\
Pertama dikawinkan & 11,9 bulan \\
Pertama beranak & $17.92 \pm 0.87$ bulan \\
Rerata Umur sapih & 3,5 bulan
\end{tabular}

152 | Performa Produksi Dan Potensi Pendapatan Usaha Ternak Kambing Perah Di Kabupaten Lumajang 


\begin{tabular}{ll} 
Calving interval & $4.07 \pm .1 .8$ bulan \\
Rata-rata pertambahan ternak/thn & $5.52 \pm 4.11 \mathrm{ekor}$ \\
\hline
\end{tabular}

Sumber : data terolah 2018

Sistem perkawinan dilakukan secara alami. Menurut Atabani et al pejantan kambing mempunyai rataan perkawinan dilakukan 2 kali (Service), sebelumnya Toelihere (1981) dan Suwardi (1987) dalam antabani et al, menyatakan banyaknya perkawinan per kebuntingan pada kambing PE adalah 1-2 dan 1,14 kali.

Kambing peranakan etawa diketahui pertama kali birahi umur $9.5 \pm 2.89$ bulan. Sedangkan umur pertama kali dikawinkan umur 11,9 bulan. Umur kawin pertama pada kambing peranak etawa senduro ini lebih baik daripada yang dilaporkan, Devendra (1990) 12 bulan dan Pralomkarn (1996) 10-12 bulan. Pertama kali beranak kambing peranakan etawa senduro ber umur $17.92 \pm 0.87$ bulan. Sedangkan rata-rata umur sapih 3,5 bulan.

Calving interval atau selang beranak kambing etawa senduro $4.07 \pm .1 .8$ bulan ratarata lebih cepat dibanding selang beranak kambing PE yang dilaporkan Sitorus et al. (1982). Rata-rata pertambahan ternak per tahun 5.52 \pm 4.11 ekor.

\section{Potensi pendapatan usaha ternak ternak}

Hingga saat ini permintaan susu kambing terus meningkat, karena susu kambing memiliki manfaat yang lebih dibanding sengan susu sapi. Hasil penelitian diperoleh potensi ekonomi usaha ternak kambing etawa sebagai berikut.

Tabel 3. Potensi ekonomi ternak

\begin{tabular}{ll}
\hline Parameter & Rata-rata \\
\hline Produksi susu peternak & $3,84 \mathrm{Lt} / \mathrm{hari}$ \\
Kelahiran anak & 5,52 ekor/tahun \\
Harga susu & Rp. 13.150,-/liter \\
Harga sempe lepas sapih & Rp. 1750.000,-/ ekor \\
\hline
\end{tabular}

Sumber : Data Terolah 2018

Berdasarkan hasil survey pada daerah penelitian ini didapatkan produktifitas ternak kambing etawa sebagai penghasil susu dan penghasil daging. Potensi susu yang dihasilkan oleh peternak setiap hari berkisar antara 3,84 Lt/hari dengan harga susu per liter berkisar antara Rp. 13.150,-/lt. Potensi produksi susu kambing pernah dilaporkan oleh Obst dan Napitupulu (1984) yaitu sebanyak. 0,45 - 2,1 1/hari/laktasi. Sementara itu produksi susu yang dilaporkan oleh Sutama et al. (2002) yaitu berkisar pada 5101000ml/ekor/hari. Sehingga potensi pendapatan harian dari usaha ternak kambing etawa senduro yang diperah susunya dapat mencapai Rp. 50.496/hari. Harga yang sangat 153 | Performa Produksi Dan Potensi Pendapatan Usaha Ternak Kambing Perah Di Kabupaten Lumajang 
menarik karena harga susu kambing jika dibandingkan harga susu sapi lebih mahal. Menurut Asmoro (2012), susu kambing murni dijual seharga Rp 9.000 / liter.

Hasil produksi ternak kambing etawa dapat melahirkan anak berkisar 5,52 ekor/ peternak per tahun. Harga cempe kambing etawa senduro lapas sapih di tingkat peternak di Kabupaten Lumajang dapat berkisar Rp. 1750.000,-/ekor. Usaha peternakan kambing etawa senduro ini mendapatkan tambahan pendapatan dari penjualan cempe lepas sapih per tahun dapat mencapai Rp. 9.660.000/ tahun.

\section{KESIMPULAN}

Berdasarkan hasil penelitian dapat disimpulkan beberapa hal sebagai berikut;

1. Jumlah ternak yang dipelihara sebanyak 12.27 \pm 9.62 ekor, sudah menguntungkan secara ekonomi bagi peternak

2. Sistem perkawinana secara alami dapat meningkatkan performa ternak kambing etawa.

3. Usaha ternak kambing etawa senduro di kabupaten lumajang memiliki potensi besar sebagai penghasilan peternak yaitu mencapai 9.660.000/tahun dari penjualan cempe dan pendapatan harian sebesar Rp. 50.496/hari dari penjualan susu.

\section{Saran}

Usaha ternak kambing etawa senduro membutuhkan perhatian khusus dari pemerintah, hal ini karena ternak kambing etawa senduro merupakan plasmanutfah ternak kambing indonesia, sehingga perlu di jaga kelestariannya. Selain itu untuk meningkatkan konsumsi susu kambing perlu untuk dipromosikan secara terus menerus, sehingga susu yang di produksi dapat terserap oleh pasar.

\section{Daftar pustaka}

Anonim. 2018. Diakses pada tangga 18 agustus 2018. Data populasi ternak kecil kab.Lumajang, periode : tribulan II 2018. https://lumajangkab.go.id/profil/ternak_kecil.php.

Asmoro, N. 2012. Peluang bisnis susu kambing. Tugas Akhir. Jurusan Manajemen Informatika. Sekolah Tinggi Manajemen Informatika dan Komputer. Amikom, Yogyakarta.

Batubara, A, S.Nasution, Subandriyo, I.Inounu, B.Tiesnamurti, dan A.Anggraeni. 2016. Kambing Peranakan Etawah (PE). Indonesian agency for agricultural Research and development (IAARD) press, jakarta. 
BPS Jawa Timur, 2016. Diakses pada 18 Agustus 2018. https://jatim.bps.go.id/statictable /2018/01/31/783/populasi-ternak-kecil-menurut-kabupaten-kota-di-provinsijawa-timur-2016.html.

[BSN] Badan Standardisasi Nasional. 2008. SNI 7352:2008 Bibit Kambing Peranakan Ettawa (PE). Jakarta (ID): Badan Standardisasi Nasional.

Budiarsana, IGM dan Sutama I.K. 2006. Karakteristik produktivitas kambing Peranakan Etawah. Prosiding lokakarya nasional pengelolaan dan perlindungan sumber daya genetik di Indonesia: manfaat ekonomi untuk mewujudkan ketahanan nasional. Bogor (Indonesia): Puslitbangnak. hlm.215-220.

Devendra, C. 1993. Kambing dan domba di Asia. Dalam : Produksi Kambing dan Domba di Indonesia. Editor : M. Tomaszewska, I. M. Mastika, A. Djajanegara, S. Gardiner dan T. R. Wiradirya. Sebelas Maret University Press, Yogyakarta.

Devendra, C. \& M. Burns. 1994. Produksi Kambing di Daerah Tropis. Terjemahan. Penerbit ITB, Bandung.

Obst, J.M. and Z. Napitupulu. 1984. Milk yields of Indonesian goats. Proc. Aust. Soc. Anim.Prod. 15: 501-504.

Priyanto, D., M. Martawijaya, dan B. Setiadi, 2004. Analisis Kelayakan Usahaternak Kambing Lokal Pada Berbagai Skala Pemilikan. Seminar Nasional Teknologi Peternakan dan Veteriner 2004.

Sarwono, B. 2001. Beternak Kambing Unggul.Penebar Swadaya. Jakarta

Sodiq, A. \& Z. Abidin. 2009. Meningkatkan Produksi Susu Kambing Peranakan Etawah. Cetakan Kedua. Agromedia Pustaka, Jakarta.

Sutama, I. K. \& I. G. M. Budiarsana. 1997. Kambing Peranakan Etawah penghasil susu sebagai sumber pertumbuhan baru sub-sektor peternakan di Indonesia. Seminar Nasional Peternakan dan Veteriner. Balitnak, Ciawi, Bogor, pp. 156167. 